UDC: 159.922

\author{
Olena Horova, \\ Doctor of Psychology, associate professor, Head of Socio-Psychological Technology Laboratory, \\ Institute of Social and Political Psychology \\ 15, Andriivska Str., Kyiv, Ukraine, \\ professor, Department of Practical Psychology, Institute of Criminal Executive Service, \\ 4, Kolektorna Str., Kyiv, Ukraine
}

\title{
TO THE ISSUE OF PSYCHOLOGICAL SUPPORT OF YOUNG MEN WITH DRUG ADDICTION EXPERIENCE
}

The paper outlines the features of providing psychological support for young men with drug addiction experience. The peculiarities of adolescents' perception of their way of life, as well as the structure of life perspective as the mechanism of youth's drug addiction have been analysed. The main principles of development and stages of implementation of the programme of psychological support for persons taking rehabilitation course after drug addiction have been presented. The results obtained show the subjective lifeline break and shifting of the evaluation of some events to revaluation of negative events and ignoring the positive ones.

Keywords: life path, life perspective, professional formation, drug addiction.

\section{Introduction}

Crisis stages of society development are reflected, first of all, in the status and social efficiency of youth. Drug addiction among young men belongs to one of the most acute social issues of the Ukrainian society today. The problem is complicated also by criminal liability of the persons who use and distribute drugs. On the other hand, readiness for using psychoactive substances is caused by impossibility to satisfy vital social requirements. With this in mind, there is a problem of reformatting the system of psychological work not only within the rehabilitation centres, but also in the penitentiary system itself. Besides, the problem of professional formation of the young men, who are at the stage of re-socialisation, is important, since the rejection of using drugs does not solve social problems and does not provide any successful entry into society. Therefore, psychological support of such persons must obviously deal with activation of internal resources, stimulate the development of adequate life perspectives, personal growth, reflection in particular, its different types and levels.

Methodological bases of research of motivational and sense spheres of a personality are put in works of Soviet psychology classics A. Leontiev, S. Rubinshtein, and developed within axiopsychological views (L. Antsyferova, B. Bratus, A. Asmolov), subject approach (K. Abulkhanova-Slavska), modern Ukrainian psychology (M. Boryshevskyi, Z. Karpenko, V. Tatenko); define main vectors of studying personality's motivational sphere in the context of its living space as the main driving force of all forms and types of activity. Fair and relevant ones are ideas of B. Bratusem, A. Leontiev about misstatement of motivational and value sphere of a personality according to the scheme "motive shift to the purpose" that accompanies all forms of dependences and reflects fundamental changes in structure of a personality [2]. These statements have something in common with V. Frankl's regulations on life-organising function of meanings that provide personality's existence with values and purposes [12]

Undeniable thesis is the one on vector development of young men in direction of individualisation and selfrealisation, creation of one's own future (I. Kon, B. Panok, T. Tytarenko), which is the main mechanism for establishing and maintaining emotionally rich contacts with peers, forming a life perspective. Life strategy and life perspective are combined in a value context: as a system of values and objectives making life more efficient (T. Buiakas), as a way of realised and structured development of the future by a personality (T. Tytarenko), including prediction of rather distant significant events of the future (K. Abulkhanova-Slavska, V. Panok). Personal perspective appears as a sequence of purposes and time limits of their realisation $[1 ; 3 ; 10 ; 11]$. In adolescence, life plans are built as a result of integration and hierarchy of a personality around the core of value orientations and, as a result, differences of close and distant perspective of one's own development.

One of the mechanisms of creation of the life perspectives for young men is their professional development as a socio-cultural component of the process of personality formation in general, that allows it to be guided effectively in a social and professional environment. At the same time, self-development in a profession should be interpreted as a capability of a person for creative selfrealisation, self-designing of activity which is shown through the choice of strategy on the basis of certain values. The structure of professional formation joins the elements of the subjective scheme, which reflect belonging to social and professional communities (D. Abrams, N. Kuzmina, G. Markus, P. Shavyr, D. Yuzerman), beliefs and values which are the manifestation of the estimative and semantic components (K. Vilpert, E. Gevorkian, A. Romanova, T. Stefanenko, etc.). Thus, professional 
development is one of the structural components of creation of a life perspective.

According to K. Abulkhanova-Slavska's thesis, regulation of time by a personality is carried out in threedimensional system of coordinates: realising of time, emotional experience, and practical organisation of activity time. A decisive importance in this case is taken on the individual activity as the ability to use the time [1]. The characteristics of life perspective are awareness, depth, and substantive content. An unproductive way of life is experienced by the personality as a crisis (A. Kronyk, E. Holovakha) [7].

Violation of a life perspective and temporal disorientation is a consequence of social crises. The use of psychoactive substances in adolescence is polymotivated where, along with characterologic lines (A. Lichko) and age tendencies to self-actualisation (I. Kon), social factors (A. Kronik) work. One of the factors of drug use is a life perspective distortion, violation of professional development processes, in particular the curvature of one or both of its vectors: 1) a vector of professional development that reflects changes of a person in the context of a wide social and professional environment "I and profession"; 2) a self-development vector that reflects changes of a person in the context of internal transformations "I - I am a selforganising professional" and is connected with internal activity of the person.

The use of psychoactive substances is a protective reaction of young men in the state of frustration, distress in situations of impossibility of construction and realisation of desirable (or adequate to opportunities) life perspective, as well as the professional one. Psychoactive substances cause deformation of the system of motives and values of an individual in the direction of replacing the real life by the illusory one (B. Bratus, V. Zavialov) [2; 5].

There is a need for further analysis of reflection of life perspectives of persons who used narcotic substances, and the construction of psychological support programme at the stage of getting rid of drug addiction, which is carried out in re-socialisation centres and in prisons.

There is an assumption that a prerequisite for success of re-socialisation course is awareness of the life perspective by the personality, involving the realisation of its own resources for self-realisation. The principles of psychological assistance to persons with experience of using narcotic substances are based on a personal reflection as the mechanism of personal development, creation of adequate life and professional formation.

\section{Discussion}

We proceed from the position of re-socialisation of drug addicts as a multicomponent process, which is aimed at restoration of moral, mental and physical condition of a person, his/her social functions, bringing the individual and collective behaviour in accordance with generally accepted social rules and norms [13]. In this connection, there is a need to develop a complex of measures aimed at preparing young men with experience of drug use for returning to a healthy lifestyle and building effective social relations. Such training is usually carried out in resocialisation centres or in penitentiary institutions and involves a team of specialists, including psychologists and social workers.

The psychological component of this programme is based on the principles of unity of consciousness and activity, taking into account the individual characteristics of the participants. Thus, the task of the psychologist comes down to encouraging young men for conscious desire of changes, help them in awareness of their own perspective and psychological support in realisation of the existing perspectives (life and professional). At the same time, it is necessary to consider that the majority of nonstate programmes of re-socialisation familiarise drug addicts with Christian faith as a basis, the main position of which is partial delegation of responsibility for the person's future to higher forces. Therefore, individual focus of the programme is caused by distinctions of young men in accepting liability for the life, a capability for reflexive self-knowledge and possessing internal resources for recovery. The complex research of reflection of resources of life perspective creation by the persons having experience of using drugs, with the use of methods of free autobiography, meaning-life orientation (D. Leontiev), technique of studying the dynamics of abilities (O. Muzyka) has been conducted for this purpose, which makes it possible to describe the spheres of life and their value for building socially acceptable future $[8 ; 9]$.

The majority of the events which are marked out by the participants $(70 \%)$ belong to the categories of inner world whereas events of professional activity have gained much less impression (35\%). Considering the leading value of the professional sphere in creation of life perspective of young men, it is important to highlight two tendencies of self-realisation in the professional sphere of drug addicts: the problems of professional formation, connected with lack of professional education owing to drug abuse; the difficulties connected with work loss (in the past these participants had work which, however, was perceived not as professional activity, but as "earning money"). The use of drugs, apparently, is caused by impossibility of satisfying the highest requirements, which do not relate to material wealth ("easy money, and nothing to do", "earned, and nothing of interest"). The important one is the participants' reflection of structure changes of their own motivation under the influence of narcotic substances, destruction of the interpersonal relations with relatives and friends, as well as the problems with employment and professional self-realisation. The picture of life of drug-addicted young men has accurate differentiation in a continuum "past" - "present-future". Negative emotional colouring of the past is caused by their subjective alienation in the form of statements of moral and ethical character ("I was silly"). Lack of emotions and the passive life strategy of young men (as dependence on other people), obviously, belong to the reasons for drug addiction. Positive emotional colouring of the present and the conflict of the image of their own "self", obviously, is 
a consequence of familiarising with Christian values: the internal conflict is described through opposition of "faith" at the cognitive level and "confrontation with people around" on behavioural one ("Only faith will help me to overcome difficulties. People should support me"). The conflict of values "getting rid of addiction" and "positive attitude" illustrates the internal barriers in overcoming drug addiction connected with experience of negative conditions during abstention from the use of narcotic substances. The image of the unrealistic successful future as a result of external "highest" influence demonstrates incomplete recovery, criticality in the perception of current situation of life and domination of the external locus of control and lack of ability to take responsibility for their actions, past and future. At the same time, the subjectively significant ones are "work", "responsibility" and "care" which reflect conscious planning of own future, which is a resource for relationships with family, freedom. The list of subjectively significant life events serves as confirmation of these results, which are marked out by young men at various stages of re-socialisation. Dynamics of awareness of their own way of life concerns quantitative relationships and time localisation of events with negative and positive emotional coloration. At the initial stages of resocialisation, domination of a vector of perception "to the past" is observed. Events of the past are accurately localised both in a time continuum and characters, and in the nature of influence (about $70 \%$ of the mentioned events are perceived as injuring, those which have led to the use of narcotic substances). The expected future developments are undifferentiated, but only positively stained ("build my life", "to take a step into the future", "I want to help people"). For the participants finishing a re-socialisation course, while maintaining total fixation on the past, a bit bigger representation of future events is characterised. The future is more differentiated ("to marry the girlfriend in three months"), however the subjectivity of these events is uncertain (the formulation "it is necessary to be recovered at university...") that leaves doubtful awareness of their own activity and responsibility in creation of life perspective. Lack of events of the present is common for the both studied groups. Besides, the participants do not rely on their past positive experience in planning their own future (availability of abilities to do business, to play sports, etc.).

Such an image of one's own life demonstrates lack of awareness of clear perspective in life that can be seen as a threatening factor of return to drug experience after completion of re-socialisation course.

The results of the research allow us to plan the directions of psychological support of the young men having experience of drug use:

- the main resource of restoration of social connections and personal development is faith, which gives the strength for overcoming their problems;

- the correlation of the constructs "getting rid of addiction" and "relationship with family" demonstrates waiting for help from a close social environment;

- the expectations of success in professional activity, in the absence of reflection and realistic means of its achievement, require focusing on the creation of an adequate view of capabilities of the young men taking a resocialization course.

The system analysis of the results allows to construct the comprehensive programme of social and pedagogical support of re-socialisation of drug addicts. The important component of this program is the psychological technology of a reflexive line of an adult personality (capable to be responsible for his/her actions) and future professional, which allows the person to objectify the significant components of his/her way of life (including professional), directs to a reflection of the purposes, motives, values; orients to the conscious choice of strategy of selfdevelopment in a profession and life in general. The offered psychological technology has the following tasks:

- participants' awareness of their own skills and abilities, as well as their importance to restore the full life;

- creating the conditions for reconstruction and development of elementary professional, communicative abilities of the participants.

Introduction of psychological technology of actualisation of a reflexive attitude of young men with narcotic experience in creation of life perspective is carried out consistently through individual consultation meetings, namely training, and the organisation of interaction of participants with the social workers involved into the resocialisation course. The interaction between the participants and employees is aimed at creating a situation of success, possibly connected with subjectively successful abilities (sports activities, production of prototypes of information posters, primary professional activity) and stimulation of emphasising the participants' progress in different types of socially useful activities.

The developed program consists of several stages:

- the studying of a reflection of the opportunities and abilities which have value capacity;

- a training intended for the formation of the axiological attitude of drug-addicted young men to life and profession, providing introduction of a new activity and moral constructs, creation of a new model of value consciousness which corresponds to problems of professional development [4]. The main idea of the training is reconstructing and actualising the subject values, which promote the development of professional capabilities, being guided by real value experience of a person and using it as a basis.

- self-monitoring of changes in the structure of opportunities and abilities and re-reconstruction of axiological components of abilities (the fourth and fifth stages) have the delayed action and are implemented in a situation of inclusion in real social relations (after the completion of re-socialisation).

\section{Conclusions}

The process of re-socialisation of the consequences of drug addiction in adolescence is a difficult multidimensional process which is developed in the course of a personality's life. Modern scientific research shows that the basis of the restoration of social relations is the construction of adequate life perspective, where components of 
professional formation are central. The view of drug addicts' way of life is violated because of subjective rupture of a lifeline and shift of assessment of separate events in the direction of revaluation of negative actions. The effective system of psychological support relies on the updat-

\section{ЛІТЕРАТУРА}

1. Абульханова К. А., Березина Т. Н. Время личности и время жизни / К. А. Абульханова, Т. Н. Березина. - СПб. : Алетейя, 2001. - 304 с.

2. Братусь Б. С. Аномалии личности / Б. С. Братусь. - М. : Мысль, 1988. - 304 с.

3. Буякас Т. М. Проблема и психотехника самоопределения личности / Т. М. Буякас // Вопросы психолологии. - 2002.- № 2. - С.28-39.

4. Горова О. О. Психологія професійного становлення майбутніх архітекторів і будівельників : Монографія / О. О. Горова - Ніжин : вид-во ПП Лисенко М. М., 2013. $359 \mathrm{c}$.

5. Короленко Ц. П., Завьялов В. Ю. Личность и алкоголь / Ц. П. Короленко, В. Ю. Завьялов. - Новосибирск : Наука, Сибирское отделение, 1987. - 170 с.

6. Кон И. С. В поисках себя : Личность и ее самосознание / И. С. Кон. - М. : Политиздат, 1984. - 335 с.

7. Кроник А. А., Головаха Б. И. Психологическое время личности / А. А. Кроник, Б. И. Головаха. - Киев : Наукова думка, 1984. - 180 с.

8. Леонтьев Д. А. Тест смысложизненных ориентаций (СЖО) / Д. А. Леонтьев. - 2-е изд. - М. : Смысл, 2000. $-18 \mathrm{c}$.

\section{REFERENCES}

1. Abulkhanova, K. A., \& Berezina, T. N. (2001). Vremya lichnosti $i$ vremya zhizni [Time of a personality and lifetime]. St. Petersburg: Aleteyya [in Russian].

2. Bratus, B. S. (1988). Anomalii lichnosti [Personal abnormalities]. Moscow: Mysl [in Russian].

3. Buyakas, T. M. (2002). Problema i psikhotekhnika samoopredeleniya lichnosti [The issue of psychotechnics and personal self-determination]. Voprosy psikhologii Issues of psychology, 2, 28-39 [in Russian].

4. Gorova, O. O. (2013). Psykholohiia profesiinoho stanovlennia maibutnikh arkhitektoriv $i$ budivelnikiv: Monhgrafiia [Psychology of professional development of future architects and engineers: monograph]. Nizhin: Vyd-vo PP Lysenko M. M [in Ukrainian].

5. Korolenko, Ts. P., \& Zavyalov, V. Yu. (1987). Lichnost $i$ alkogol [Personality and alcohol]. Novosibirsk: Nauka, Sibirskoe otdelenie [in Russian].

6. Kon, I. S. (1984). V poiskakh sebya: Lichnost i ee samosoznanie [Looking for one's place in the world: Personality and its self-awareness]. Moscow: Politizdat [in Russian].

7. Kronik, A. A. \& Golovakha, B. I. (1984). Psikhologicheskoe vremya lichnosti [Personality's psychological time]. Kyiv: Naukova dumka [in Russian].

8. Leontyev, D. A. (2000). Test smyslozhiznennykh orientatsii (SZhO) [Test of life-purpose orientation]. $2^{\text {nd }}$ ed., rev. Moscow: Smysl [in Russian]. ing of young men's own value-related experience, understanding their own opportunities and capabilities as internal resources for search of means and ways of professional formation and, at last, life perspective.

9. Музика О. Л. Рефлексія і динаміка розвитку здібностей: підходи до побудови методики дослідження / О. Л. Музика // Здібності, творчість, обдарованість : теорія, методика, результати досліджень ; за ред. В. О. Моляко, О. Л. Музики. - Житомир : Вид-во Рута, 2006. - С. 50-54.

10. Панок В. Г., Рудь Г. В. Психологія життєвого шляху особистості : Монографія / В. Г. Панок, Г. В. Рудь. - К. : Ніка-Центр, 2006. - 280 с.

11. Титаренко Т. М. Життєвий світ особистості : у межах і за межами буденності / Т. М. Титаренко. К. : Либідь, 2003. - 376 с.

12. Франкл В. Человек в поисках смысла : Сборник / В. Франкл; пер. с англ. и нем. / Общ. ред. Л. Я. Гозмана и Д. А. Леонтьева. - М. : Прогресс, 1990. - $368 \mathrm{c}$.

13. Юридична енциклопедія : В 6 т. [Електронний ресурс] / Редкол.: Ю. С. Шемшученко (голова редкол.) та ін. - К. : «Укр. енцикл.», 1998. - Режим доступу: http://leksika.com.ua/legal/.

9. Muzyka, O. L. (2006). Refleksiia i dynamika rozvytku zdibnostei: pidkhody do pobudovy metodyky doslidzhennia [Reflecion and dynamics of capabilities development: approaches to the creating of research methodology]. Zdibnosti, tvorchist, obdarovanist: teoriia, metodyka, rezultaty doslidzhen - Capabilities, creativity, talent: theory, methods, research results. (pp. 50-54). V. O. Molyako, O. L. Muzyka (Ed.). Zhitomir: Vyd-vo ruta [in Ukrainian].

10. Panok, V. H., \& Rud, H. V. (2006). Psykholohiia zhittievoho shliakhu osobystosti: Monohrafiia [Psychology of personality's life path: monograph]. Kyiv: NikaTsentr [in Ukrainian].

11. Titarenko, T. M. (2003). Zhittievyi svit osobystosti: $u$ mezhakh $i$ za mezhamy budennosti [Lifeworld of a personality: within and beyond the bounds of everyday routine]. Kyiv: Lybid [in Ukrainian].

12. Frankl, V. (1990). Chelovek v poiskakh smysla [A man in search of the sense]. L. Ya. Gozman and D. A. Leontyev (Eds.). Moscow: Progress [in Russian].

13. Yurydychna entsyklopediia [Legal encyclopedia]. (1998). Yu. S. Shemshuchenko (Ed.). Kyiv: "Ukrainska entsyklopediia". Retrieved from: http://leksika.com.ua/legal/ [in Ukrainian]. 
Олена Олександрівна Горова, доктор психологічних наук, дочент, завідувач лабораторії сочіально-психологічних технологій, Інститут соияіальної та політичної психології, вул. Андріївська, 15, м. Київ, Україна, професор кафедри практичної психології, Інститут кримінально-виконавчої служби, вул. Колекторна, 4, м. Київ, Украӥна

\section{ДО ПРОБЛЕМИ ПСИХОЛОГІЧНОГО СУПРОВОДУ ЮНАКІВ ІЗ ДОСВІДОМ НАРКОТИЧНОЇ ЗАЛЕЖНОСТІ}

Кризові періоди в соціальному розвиткові супроводжуються збільшенням кількості та інтенсивності особистісних деформацій, які стосуються, як правило, представників молодших поколінь. Однією з актуальних проблем залишається зростання наркотизації серед молодих людей, яка супроводжується викривленням ціннісно-смислової сфери і тягне за собою порушення процесів адекватного входження в суспільні відносини. Результатом цих процесів все частіше стає перебування в органах пенітенціарної системи. Традиційні методи психологічного впливу грунтуються на формуванні нових мотивів і цілей діяльності. Сучасні дослідження підтверджують тезу про взаємозв'язок життєвої перспективи та професійного самовизначення. Актуальним є пошук шляхів формування адекватної життєвої перспективи, що сприяє професійному становленню та самореалізації осіб, що мають досвід наркотичної залежності. У роботі представлено аналіз особливостей сприйняття власного життєвого шляху, структури життєвої перспективи як механізмів виникнення наркотичної залежності юнаків. Результати дослідження свідчать про суб'єктивний розрив лінії життя (випадання переживань теперішнього) та зміщення оцінки окремих подій в напрямку переоцінки негативних подій і нівелювання позитивних. Розкриваються основні принципи побудови та етапи реалізації програми психологічного супроводу осіб, які проходять курс реабілітації після наркотичної залежності. Основним діючим механізмом є усвідомлення ціннісного досвіду і власних можливостей і здібностей як ресурсів побудови адекватної життєвої перспективи і майбутнього професійного становлення.

Ключові слова: життєвий шлях, життєва перспектива, професійне становлення, наркотична залежність.

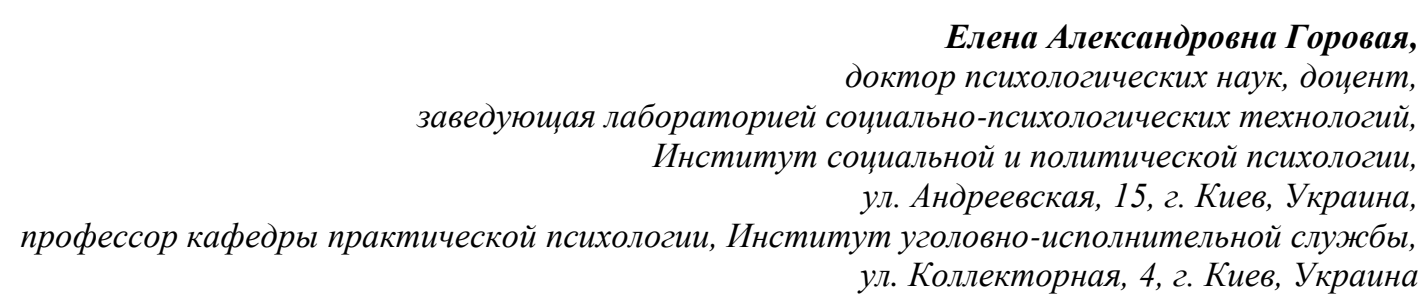

\section{К ПРОБЛЕМЕ ПСИХОЛОГИЧЕСКОГО СОПРОВОЖДЕНИЯ ЮНОШЕЙ С ОПЫТОМ НАРКОТИЧЕСКОЙ ЗАВИСИМОСТИ}

Кризисные периоды в социальном развитии сопровождаются увеличением количества и интенсивности личностных деформаций, которые касаются, как правило, представителей младших поколений. Одной из актуальных проблем остается рост наркотизации среди молодых людей, которая сопровождается искривлением ценностно-смысловой сферы и влечет за собой нарушения процессов адекватного вхождения в общественные отношения. Результатом этих процессов все чаще становится пребывание в органах пенитенциарной системы. Традиционные методы психологического влияния основываются на формировании новых мотивов и целей деятельности. Современные исследования подтверждают тезис о взаимосвязи жизненной перспективы и профессионального самоопределения. Актуальным является поиск путей формирования адекватной жизненной перспективы, способствующей профессиональному становлению и самореализации лиц, имеющих опыт наркотической зависимости. В работе представлен анализ особенностей восприятия собственного жизненного пути, структуры жизненной перспективы как механизмов возникновения наркотической зависимости юношей. Результаты исследования свидетельствуют о субъективном разрыве линии жизни (выпадение переживаний настоящего) и смещении оценки отдельных событий в направлении переоценки негативных событий и нивелирования позитивных. Раскрываются основные принципы построения и этапы реализации программы психологического сопровождения лиц, проходящих курс реабилитации после наркотической зависимости. Основным действующим механизмом является осознание ценностного опыта и собственных возможностей и способностей как ресурсов построения адекватной жизненной перспективы и будущего профессионального становления.

Ключевые слова: жизненный путь, жизненная перспектива, профессиональное становление, наркотическая зависимость.

Подано до редакиії 18.11.2016 